\title{
The semantics of the aan-construction in 16th-century Dutch: A semasiological and onomasiological approach
}

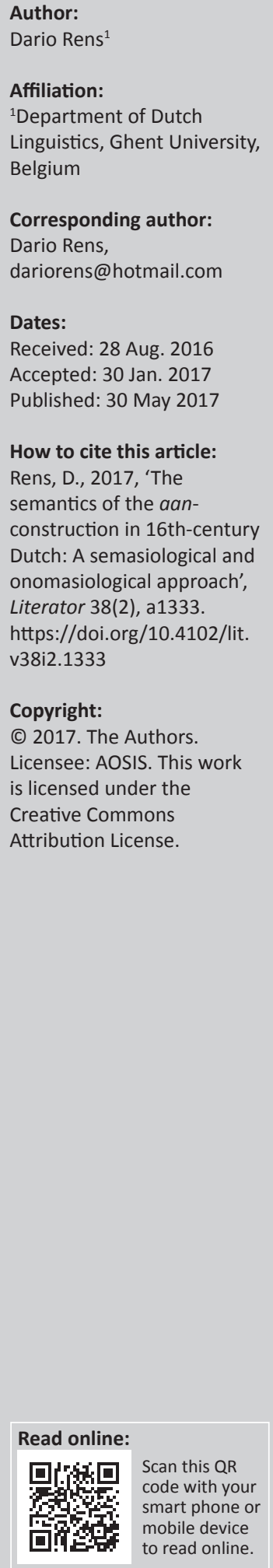

This article focuses on the semantics of the Dutch aan-construction [NP V NP aan NP], for example, Jan geeft een boek aan Piet ('Jan gives a book to Piet') in the 16th-century. In modern Dutch the aan-construction is used as an alternative to the Dutch double object construction, but previous research suggests that the use of ditransitive verbs in the Dutch aan-construction is only a 16th-century innovation - this alternation is called the 'dative alternation'. However, it is not clear which ditransitive verbs initiated the dative alternation. Colleman (2010) believes that the first instances of the ditransitive use of the aan-construction are concrete physical movements of the direct object from the subject to the indirect object; however, he argues there is no quantitative proof to support those claims. In a self-compiled corpus of 16th-century Dutch, this article tries to find the evidence which is needed to underpin Colleman's hypothesis by making use of the distinctive collexeme analysis and its diachronic variant. The results show that the first ditransitive instances of the aan-construction are indeed concrete uses, but that there is also an increase in the metaphorical use of the construction.

Die semantiek van die aan-konstruksie in sestiende-eeuse Nederlands: 'n Semasiologiese en onomasiologiese benadering. Hierdie artikel fokus op die semantiek van die Nederlandse aankonstruksie [NP V NP aan NP], byvoorbeeld Jan geeft een boek aan Piet ('Jan gee 'n boek aan Piet') in die sestiende eeu. In moderne Nederlands word die aan-konstruksie gebruik as 'n alternatief vir die Nederlandse dubbelobjekkonstruksie, maar navorsing dui daarop dat die gebruik van ditransitiewe werkwoorde in die Nederlandse aan-konstruksie slegs 'n sestiende-eeuse verskynsel is - hierdie afwisseling staan bekend as die 'datiefafwisseling'. Dis egter nie duidelik watter ditransitiewe werkwoorde die datiefalternansie geïnisieer het. Colleman (2010) glo dat die eerste gevalle van die ditransitiewe gebruik van die aan-konstruksie konkrete fisiese bewegings is waarby die direk objek van die subjek na die indirek objek beweeg. Hy argumenteer egter dat daar geen kwantitatiewe bewys is om die bewerings te staaf nie. In 'n selfsaamgestelde korpus van sestiendeeeuse Nederlands probeer hierdie artikel die bewyse vind om Colleman se hipotese te ondersteun en sal die distinktiewe kollekseemanalise en sy diakroniese variant gebruik. Die resultate dui daarop dat die eerste ditransitiewe gevalle van die aan-konstruksie inderdaad konkrete gebruike is, maar dat daar ook ' $n$ toename is in die metaforiese gebruik van die konstruksie.

\section{Introduction}

One of the significant evolutions in construction grammar is the growing interest in language variation and language change. Concerning diachronic research, there are two milestones: (1) the monograph of Traugott and Trousdale (2013), in which a coordinating theory is presented on the rise of new constructions or constructionalisation, and (2) the volume Diachronic construction grammar (Barðdal et al. 2015), the first instalment of the prestigious series Constructional Approaches to Language which is completely devoted to diachrony. Colleman and De Clerck (2011:184-185) point out that within diachronic construction grammar the focus is more on constructionalisation. Though they underline the importance of that kind of research, they think there is a need for diachronic research on semantic syntactic changes within existing constructions, what Traugott and Trousdale (2013) call post-constructionalisation constructional changes. A study of the shifts within the semantic network of a construction could yield interesting results. A comparison between language data of one construction over four different time periods could, for example, show that certain meanings have decreased or increased in use (quantitative semantic shift), while other meanings could have disappeared or been added to the constructicon (qualitative semantic shift) (Colleman 2011:402). Colleman and De Clerck (2011) show that the English double object construction has gone through a process of semantic specialisation and lost some of its meanings from the periphery, for example, the meaning connected to verbs of banishment. 
In this article, we will discuss the semantics of the so-called prepositional dative construction with aan - or in shorter terms the aan-cx - in 16th-century Dutch; a construction which during that period was even less of an alternative to the double object construction than nowadays (see The Dutch aanconstruction section). Colleman (2010) has shown that the core meaning of the aan-construction is 'contact' and that the younger 'transfer' meaning is a metaphorical extension. That metaphorical 'transfer' meaning was not self-evident in the 16th-century. In this study, we will examine which semantic and morphological types of verbs were already possible in the 16th-century aan-construction. In the semasiological component, we will test if there are any semantic shifts observable within the 16th-century aan-construction using a diachronic collexeme analysis (Hilpert 2006). Subsequently we will check in the onomasiological section if these shifts are also perceptible in the ratio between the 16th-century aanconstructions and double object constructions using two distinctive collexeme analyses (Gries \& Stefanowitsch 2004).

\section{Theoretical framework Construction grammar}

Construction grammar is a collective term for different theoretical approaches (compare, e.g. Croft 2001; Goldberg 1995) which share some fundamental starting points. Construction grammar assumes that constructions are 'stored pairings of form and function, including morphemes, words, idioms, partially lexically filled and fully linguistic patterns' (Goldberg 2003:219). Constructions constitute the basic units of language and are stored in a structured network, the constructicon. More than informal approaches, there is more attention to the semantic and pragmatic characteristics of grammatical patterns and to the relations between different constructions with comparable functional qualities in construction grammar. In diachronic linguistics, this translates to research of changes within these qualities or interconstructional relations, or constructional changes. This study focuses on the evolution of the constructional semantics of the aan-construction in the 16th-century. In the next section, we will go into the features of the Dutch aan-construction, and we will clarify the reason why the 16th-century aanconstruction is so interesting for further research.

\section{The Dutch aan-construction}

Dutch is one of the languages which show the intriguing phenomenon of the dative alternation. Many verbs that occur in the double object construction can also occur with an aanobject instead of a nominal indirect object. The sets of verbs which can appear in both constructions are not identical though: there are verbs that can only occur in the double object construction, for example, benijden 'envy', and there are verbs with which prepositions are obligated, for example, spenderen 'spend'. ${ }^{1}$ The dative alternation, however, was not always present in the history of Dutch.

\footnotetext{
1.The traditional grammar (see Van Belle \& Van Langendonck 1996) makes distinction between the aan-object of geven and spenderen, but De Schutter (1974) and Colleman (2010) state there is no reason to make those distinctions.
}

Dutch has been characterised for centuries by the ongoing decline of the case system or deflexion, likewise in the 16thcentury (Van Der Horst 2008:795). Because of deflexion, it became harder to distinguish the accusative from the dative and therefore it also became harder to distinguish the direct object from the indirect object. As the Middle Dutch double object construction had a relatively free word order (Rens 2014), syntactic ambiguity arose. To avoid this syntactic ambiguity, the indirect object could be marked with a preposition more often. This derives from the horror aequi principle, 'the widespread (and possibly universal) tendency to avoid the unmotivated recurrence of identical and adjacent grammatical elements or structures' (Rohdenburg 2007:220). Van Der Horst (2008:801) demonstrates with a 16th-century example that the preposition is indeed penetrating the indirect object:

(1) Ende gaf hem over anden Turck. [RC 166] (1570-1585) [And gave him over to the Turk].

In a small-scaled corpus study, Weijnen and Gordijn (1970:127) find only a few debatable examples of the aanconstruction in the 16th-century. According to them the examples still demonstrate a strong locative meaning. Weijnen and Gordijn (1970), and later Duinhoven (2003) too, assume that the productive use of the preposition aan in combination with verbs of giving is a post-medieval development. Colleman (2010:294) rightly observes that both studies do not fulfil the requirements of modern corpus research and deduces that, if their assumptions are correct, the use of aan as a prepositional marker of the 'source'-object is older than the use of aan as a prepositional marker of the recipient. Colleman (2010:295) bases that statement on examples of the 13th-century aan-construction from the VMNW (Pijnenburg 2001) ('Early Middle Dutch Dictionary'). Research on the Middle Dutch dative alternation (Rens 2014) has proven that the verb nemen 'take' was indeed compatible with the Middle Dutch aan-construction. Those observations are a good motive for further research on the semantic evolution of the aan-construction.

There is not much more known about the rise of the 'transfer' meaning of the aan-construction. Geleyn and Colleman (2015) examine the extent to which the 17th-century aan-construction covers the semantic field of the present-day construction, and how the construction has developed through time utilising a diachronic collexeme analysis. They observe that the semantic range of the aan-construction in the 17th-century Dutch covers well-nigh the complete semantic range of nowadays, and they call for a study on the 16th-century aan-construction. Everything seems to indicate that the 'transfer' meaning is a 16th-century innovation, which has developed very quickly and by the first half of the 17th-century has taken up its spot in the semantic network of the aan-construction. According to Colleman (2010), the aan-construction has expanded to the peripheral 'transfer' meaning from the central 'contact' meaning of the construction:

[D]iachronically, the use of the aan-dative with verbs of giving and closely related classes very probably originated with prototypical 'give' events which involve a physical transfer of a concrete entity (i.e., where the theme is actually moved from 
a position in the spatial proximity of the agent to a position in the spatial proximity of the recipient) and has subsequently spread to more abstract 'transfer' events. (pp. 289-290)

To illustrate the difference between the more concrete 'contact' and the more abstract 'transfer' meaning, compare (2), (3) and (4):

(2) Hij verbindt de hartslagmeter aan zichzelf. [He connects the heart rate monitor to himself].

(3) Ik overhandigde het cadeau aan hem. [I handed over the gift to him].

(4) Ik spendeerde geld aan die auto. [I spent money on that car].

Case (2) is a literal contact situation in which the aanconstruction is used. Case (3) is a concrete transfer in which a moment of contact also takes place between the direct object and the indirect object. In (4), however, there is no physical contact anymore between the direct object and the indirect object, though a transfer is still taking place. Colleman (2010) suggests the 'transfer' meaning of the aan-construction is a metaphorical extension of the original 'contact' meaning. The 'transfer' meaning of the aan-construction has further evolved and almost lost its 'contact' meaning. We will test this hypothesis in this study.

\section{Corpus and methodology}

As part of this study a new corpus was compiled of 16thcentury Dutch texts. The corpus comprises 34 texts, which are adopted from different online corpora, and is good for one million words. The texts are divided into four quarter centuries to obtain an accurate overview of the evolution of the Dutch aan-construction during the 16th-century. During the compilation of the corpus, some restrictions were applied: only texts which could be dated back accurately were chosen in order to be divided more easily in quarter centuries; all texts are prose or non-fiction, because in poetry and drama there is a predilection for archaic language and such texts are subject to limitations associated with the rhyme and metrum (Van Kemenade \& Los 2013:229); lastly, we have limited the amount of words to a maximum of 150000 words per author. ${ }^{2}$ The first quarter century (1501-1525) contains ca. 100000 words, the second quarter century (1526-1550) ca. 280000 words, the third quarter century (1551-1575) ca. 225000 words and the last quarter century (1576-1600) contains ca. 500000 words. The corpus is clearly not distributed evenly over the four quarter centuries, but since the statistical analyses take this into account, there is no drawback.

The corpus is not enriched with linguistic annotation, which makes the search for all kinds of syntactic constructions harder. In the case of the aan-construction, the fixed preposition aan makes the search query easier. The corpus was searched for different spelling variations of the preposition (aan, ane, aene, an, aande, etc.) and that yielded a total of 3757 hits. Then those hits were manually analysed to 2.The corpus is available and can be requested via email: dario.rens@ugent.be. check whether they meet Colleman's (2010) formal definition of the aan-construction: (Sbj [V $\left.\mathrm{Obj}_{1} a a n-\mathrm{Obj}_{2}\right]$ ). Only constructions which met the formal definition were included in our count, which resulted into 724 attestations (tokens) after manual analysis. In the first quarter century (1501-1525) 34 aan-constructions were tallied, in the second quarter century (1526-1550) 283, in the third (1551-1575) 116 and 291 in the fourth quarter century (1576-1600). In total 135 different verbs (types) occurred in the aanconstruction, whereof 65 only once (hapaxes). The high amount of hapaxes indicates a Zipfian distribution and thus that the 16th-century aan-construction was productive.

In the onomasiological section of this study, we will compare the distribution of the aan-construction and the double object construction. Therefore, we have also searched our corpus for double object constructions. The search for double object construction was impeded since in that construction no fixed position is filled in by definition by a certain word. Thence we have searched the corpus for 27 verbs (and their spelling variations) of which is known from previous research (e.g. Colleman 2010; Geleyn \& Colleman 2015) that they can or could occur in both constructions. The verbs are selected such that different verb classes are represented (Table 1).

The search yielded more than 5000 hits, but also these hits were subjected to a syntactic filter. To define the double object construction we used the formal definition of Colleman (2009b) [Sbj [V Obj $\left.\mathrm{Obj}_{2}\right]$ - constructions in which, for example, only one nominal object occurs, because the direct object can be derived from the context, were not included. ${ }^{3}$ We have only searched the corpus segments of the second and fourth quarter century for double object constructions, since those two quarter centuries yielded the most attestations of the aan-construction and are thus most interesting for a comparative study. After manual analysis, 564 constructions appeared to meet our syntactic filter: 223 in the second quarter century and 341 in the fourth quarter century.

TABLE 1: Overview of verbs adopted in the distinctive collexeme analysis, sorted by semantic class.

\begin{tabular}{|c|c|}
\hline Verb class & Investigated verbs \\
\hline Verbs of giving & $\begin{array}{l}\text { geven [give]; meegeven [endow]; overdragen [transfer]; } \\
\text { schenken [gift]; verkopen [sell]; wedergeven [give back] }\end{array}$ \\
\hline Verbs of bringing & dragen [carry]; brengen [bring]; overbrengen [transfer] \\
\hline Ballistic movements & werpen [throw] \\
\hline Verbs of sending & zenden [send]; overzenden [ship] \\
\hline Verbs of permission & toestaan [allow] \\
\hline Antidative verbs & ontzeggen [deny] \\
\hline Communicative verbs & $\begin{array}{l}\text { schrijven [write]; verhalen [recount]; vertellen [tell]; } \\
\text { verzoeken [request]; zeggen [say] }\end{array}$ \\
\hline Verbs of showing & tonen [show]; wijzen [point] \\
\hline Privative verbs & nemen [take] \\
\hline Action verbs & bewijzen [prove]; doen [do]; plegen [commit] \\
\hline Verbs of subjection & onderwerpen [subject] \\
\hline Attributional verbs & toeschrijven [attribute] \\
\hline
\end{tabular}

3.Passive constructions were still counted, just like in the aan-construction. 


\section{Semasiological study}

\section{Semantic field}

In the first section of our study, we will approach the aanconstruction independently to get an overview of the semantic range of the construction. On the basis of the semantic network of Geleyn and Colleman (2015:220) we will examine the meaning extensions of the 16th-century aanconstruction. The different meaning extensions we can distinguish are provided in Table 2.

The semantic area of the 16th-century aan-construction is rather limited in contrast to the 17th-century aan-construction (Geleyn \& Colleman 2015). A first large set of verbs that we find in our corpus data belongs to the first semantic extension: the subject acts to create a contact relationship between the direct object and the aan-object. Within the first semantic extension Geleyn and Colleman distinguish four subdivisions, namely concrete transfers (5), abstract transfers (6), actions (7) and communicative transfers (8). Note that Geleyn and Colleman regard actions and communicative transfers as subtypes of abstract transfers. All four subtypes of the first semantic extension can be found in our corpus:

TABLE 2: Sub-meanings of the aan-construction, according to Geleyn and Colleman (2015).

Number Semantic extensions

1 Subject acts to make a contact relationship [between DO and aan-object]

occur:

1.1 Concrete transfer:

Hij gaf een bos bloemen aan zijn vrouw.

[He gave a bunch of flowers to his wife]

1.2 Abstract transfer:

Hij schonk aandacht aan dat probleem.

[He paid attention to that problem].

1.3 Action:

Hij brengt schade toe aan het gebouw.

[He brings damage to the building].

1.4 Communicative transfer:

Hij vertelde het verhaal aan zijn dochtertje.

[He told the story to his daughter].

2 Subject promises or offers the possibility to make a contact relationship between DO and aan-object occur: Hij beloofde een auto aan zijn zoon. [He promised a car to his son].

3 Subject acts to break the contact relationship between aan-object and DO: Ze ontnam alle hoop aan de gevangenen.

[She took away all hope from the prisoners].

$4 \quad$ Subject does not act to break the contact relationship between aan-object and DO

5 Subject prevents contact between DO and aan-object: Hij weigerde bier aan minderjarigen. [He refused beer to minors].

6 Subject does not prevent contact of DO-aan-object: Hij stond de toegang toe aan de supporters. [He allowed access to the supporters]

7 Subject confirms a contact relationship or takes a stand towards the creation of a contact relationship or existing contact relationship: Ze schreven een enorme motivatie toe aan de professor. [They attributed an enormous motivation to the professor].

8 Aan-object is the starting point for contact Subject-DO: Hij zag het aan haar gezicht. [He saw it in her face].

$9 \quad$ Aan-object is the standard or influence with which DO comes in contact by Subject:

Ze toetste dat aan de reglementen.

[She checked that against the regulations].

Source: Geleyn, T. \& Colleman, T., 2015, 'De aan-constructie in het 17de-eeuwse Nederlands. Eensemasiologischestudie', Taal en Tongval 67(2), 223; Table 1

Note: The semantic network of the aan-construction differs from the semantic network of the to-dative (e.g. semantic extensions 8 and 9; see also Colleman \& De Clerck 2009).
(5) Eer de ghifte dair af gegeven es aenden amman. (before the gift there of given is on-the overseer) [Before the gift thereof is given to the overseer].

(Unknown author - Ontwerpscostumen van Mechelen)

(6) Om van daer te varen naer Portugal, ende so voorts naer Roomen, om obedientie te gheven aenden paus. (to from there to sail to Portugal, and so on to Rome, to obedience to give on-the pope) [To sail from there to Portugal, and so on to Rome, to give obedience to the pope].

(J. Huyghen van Linschoten - Itinerario)

(7) Vreemde ende wonderlicke curen, aen jonghe dochters gepleecht, als zy gheboren werden, ende als zy de bruijt zijn. (strange and wonderful manners, to young daughters committed, if they born were, and if they the bride are) [Strange and wonderful manners, committed to young daughters, when they were born, and when they are the bride].

(J. Huyghen van Linschoten - Itinerario)

(8) Op dat sy voorder brieven schreven soo aen den Keyser als Admirante, ende tot Brussel aen den Cardinael Andream van Oostenrijck, Gouverneur van Nederlandt. (on that they further letters wrote so to the Emperor as Admirer, and to Brussels to the Cardinal Andreas of Austria, Governor of Netherlands) [In order that they kept on writing letters to the Emperor as admirer, and to Brussels to Cardinal Andreas of Austria, Governor of the Netherlands].

(Unknown author - Walvisch van Berckhey)

In addition to the first semantic extension, the eighth semantic extension, wherein the aan-object acts as a starting point for the contact relationship between the subject and the direct object, is also very frequent in our data set. The aan-object does not represent a recipient in that case but a kind of source object. Semantic extension 8 is strongly represented by, inter alia, the verb nemen 'take' (9) and a number of verba sentiendi (10-11):

(9) Gij heeren, ghij dijckgraeff ende gesworens, neempt $u$ exempel aen andere. (you gentlemen, you dijkgraaf and jurors, take you example on others) [You gentlemen, you dijkgraaf and jurors, take an example from others]. (A. Vierlingh - Tractaet van dyckagie)

(10) Hoe ons ghemoet was, dat dorstmen niet raden, want wy condet aen ons wel sien. (how our mood was, that dared-one not guess, because we could-it on us indeed see) [How our mood was, they did not dare to guess, because we could see it in us].

(G. De Veer - Drie seylagien)

(11) Dit mercktmen licht an d' onwyze kindsheyd. (this perceive-one lightly on the unwise infancy) [They perceive this lightly from his unwise infancy]. (D. Volckertsz. CoornhertZedenkunst)

Een exempel nemen aan 'take an example from' is an expression that we still know nowadays, albeit with eenvoorbeeld 'an example' as direct object, and was already frequent in Middle Dutch (Rens 2014). The verba sentiendi or verbs of perception are perhaps the first verbs that could occur in the aanconstruction. When we search the ONW (Schoonheim, Louwen, Mooijaart, Pijnenburg \& Quak 2009) ('Old Dutch Dictionary') for the lemma ana, we find this instance of the aan-construction:

(12) O synagoga, thu wanderost thich thero uirtutum ande thero profectuum, thie thu ane mir scouwest. (oh synagogue, you wonder yourself the-[dative] virtues and the-[dative] successes, 
that you on me see) [Oh synagogue, you are wondering about the virtues and the successes, which you see in me].

(Leidse Willeram)

Although the analysis of the aan-constituents in (10)-(12) is up for discussion, it is likely that such uses have played an important role in the emergence of constructions in which the aan-constituent unambiguously acts as an object.

The other semantic extensions are not represented in our corpus. It is, therefore, likely that the 16th-century aanconstruction was limited to semantic extensions 1 and 8 . The remaining semantic extensions are in that case only subsequent semantic developments of the aan-construction. The numbers of Geleyn and Colleman (2015:214) seem to confirm that claim. Although each of the categories in Table 2 was detected at least several times, the majority of the 1530 aan-constructions they have found in their 17th-century corpus belongs to the semantic extensions 1 (79.3\%) and 8 $(10.7 \%)$. The other semantic extensions are less common with a maximum of $41(2.7 \%)$ attestations per semantic extension.

\section{Diachronic collexeme analysis}

The diachronic collexeme analysis is a variant of the distinctive collexeme analysis designed by Gries and Stefanowitsch (2004). The distinctive collexeme analysis is a statistical test which is used for competitive constructions, such as the double object construction and the aanconstruction, in order to detect distinctive collexemes, that is, lexemes which have a (significant) preference for one of the tested constructions. Gries and Stefanowitsch use the distinctive collexeme analysis for the English dative alternation in order to determine which verbs prefer the double object construction and which the to-dative.

Although the distinctive collexeme analysis is normally used for synchronic data, Hilpert (2006) suggested to extend the use of the statistical test to diachronic language data. This application is called the diachronic collexeme analysis. Unlike the distinctive collexeme analysis, which compares the preference of verbs for competitive constructions, the diachronic collexeme analysis compares the preference of verbs for the same constructions over different time periods. The diachronic collexeme analysis can be useful to uncover shifts in the constructional semantics on the basis of the preference of verbs for a certain period (Hilpert 2006:243). Hilpert concretises his method by calculating the distinctive collexemes of the shall-construction in three periods: $1500-1640,1640-1780,1780-1920$. On the basis of the results of his analysis, Hilpert shows that the shallconstruction has gone through a process of subjectification. ${ }^{4}$

In the table below we present the results of our diachronic collexeme analysis for the four quarter centuries of the 16thcentury, calculated with Gries (2007). The verbs showing a significant preference (95\% confidence level) for a quarter century are listed per quarter century. Next to each verb the number of times that verb is found in each period is indicated. The second number indicates the collostructional strength. ${ }^{5}$ The higher the collostructional strength, the more the collexeme occurs in that period or construction. The collostructional strength is calculated by comparing the distributions of every collexeme and construction concerned. Note that it is possible for a collexeme to occur more in period $x$ than in period $y$, but still show a preference for period $y$ as it occurs more than other verbs in period $y$. For example, the verb slaan 'hit' is a distinctive collexeme for the first quarter century but was only attested three times in the first quarter century and five times in the second quarter century, 0 times in the third quarter century and finally one time in the fourth quarter century. The collostructional strength of the verb slaan is 2.15. If the collostructional strength is higher than 1.33 , the collexeme is significantly distinctive for a certain period or construction. That means that the use of zien 'see' in the aan-construction occurs significantly more often in the fourth period than we would have expected from a random distribution of all attestations over the four quarter centuries. Eventually 22 collexemes prove to be distinctive: four for 1501-1525, four for 1526-1550, six for 1551-1575 and eight for 1576-1600 (Table 3).

Based on the results of the diachronic collexeme analysis we can draw up some hypotheses which we will test further in

TABLE 3: Distinctive collexemes of diachronic collexeme analysis of the 16thcentury aan-construction.

\begin{tabular}{|c|c|c|c|}
\hline Quarter century & Verb & $\begin{array}{l}\text { Instances per } \\
\text { quarter century }\end{array}$ & CollStr \\
\hline \multirow[t]{4}{*}{$1500-1525 \dagger$} & Slaan [hit] & $3: 5: 0: 1$ & 2.15 \\
\hline & klagen [complain] & 1:0:0:0 & 1.33 \\
\hline & Smaken [taste] & 1:0:0:0 & 1.33 \\
\hline & $\begin{array}{l}\text { Voortkondigen } \\
\text { [proclaim] }\end{array}$ & 1:0:0:0 & 1.33 \\
\hline \multirow[t]{4}{*}{ 1526-1550末 } & Verbeuren [forfeit] & $0: 50: 3: 7$ & 11.62 \\
\hline & Hebben [have] & $1: 45: 7: 14$ & 5.51 \\
\hline & aanleggen [lay on] & $0: 4: 0: 0$ & 1.63 \\
\hline & Verhalen [recount] & $0: 13: 3: 5$ & 1.54 \\
\hline \multirow[t]{6}{*}{$1551-1575 \S$} & koppelen [connect] & $0: 0: 5: 3$ & 2.41 \\
\hline & $\begin{array}{l}\text { gewaarworden } \\
\text { [sense] }\end{array}$ & $0: 0: 3: 0$ & 2.39 \\
\hline & Inbrengen [bring in] & $0: 0: 2: 0$ & 1.59 \\
\hline & Behouden [retain] & $0: 3: 4: 1$ & 1.57 \\
\hline & Zweren [swear] & $0: 2: 3: 0$ & 1.50 \\
\hline & Eisen [demand] & $0: 1: 3: 1$ & 1.50 \\
\hline \multirow[t]{8}{*}{$1576-1600$ ฯ } & Bewijzen [prove] & 0:0:0:9 & 3.56 \\
\hline & Zien [see] & $5: 0: 3: 21$ & 3.35 \\
\hline & verbinden [connect] & $0: 1: 1: 12$ & 3.19 \\
\hline & Bevinden [find] & 1:0:0:6 & 1.71 \\
\hline & Geven [give] & $0: 1: 0: 6$ & 1.71 \\
\hline & Hangen [hang] & $0: 1: 0: 6$ & 1.71 \\
\hline & Merken [perceive] & $0: 0: 3: 8$ & 1.52 \\
\hline & Schrijven [write] & $0: 5: 1: 11$ & 1.44 \\
\hline
\end{tabular}

Collstr, collostructional strength.

$\dagger, N=34 ; \ddagger, N=283 ; \S, N=116 ; \uparrow, N=291$.

5.See Gries, Hampe and Schönefeld (2005) for further reading on collostructional strength. 
this study. Before we start the discussion of our results, we want to point out that we have compared relatively short periods of time. The semantic shifts that we observe are therefore not as pronounced as the shifts that Geleyn and Colleman (2015) establish in their research. In addition, the smallest differences are also statistically significant because of that. Nevertheless, we can note some interesting findings for the semantic evolution of the 16th-century aanconstruction.

Before we discuss these findings, we would like to dwell on a discrepancy in our corpus. In the second quarter century, the verb verbeuren 'forfeit' is much more common than in the other quarter centuries, making the verb have the highest collostructional strength (11.62) of the investigated verbs. That high score, however, is due to the legal text genre that dominates the corpus of the second quarter century. Verbeuren 'forfeit' is, in fact, a verb found primarily in legal language, as evidenced by the definition of verbeuren 'forfeit' in the WNT (De Vries \& Te Winkel 1882-1998) ('Dictionary of Dutch Language'): 'By your own fault losing anything worthwhile, respectively the right or the enjoyment of it'. That the verb verbeuren 'forfeit' shows a preference for the second quarter century has more to do with the content of the corpus, than with any semantic shifts. Obviously apart from the discrepancy in our corpus, there are some remarkable findings in our corpus.

Verbs with which the aan-object acts as a starting point for the contact relationship between the subject and the direct object appear to have at least one distinctive collexeme in every quarter century: for the first quarter century the distinctive collexeme is smaken 'taste' (1.33), for the second quarter century hebben 'have' (5.51), for the third quarter century gewaarworden 'sense' (2.39) and finally for the fourth quarter century zien 'see' (3.35), bevinden 'find' (1.71) and merken 'perceive' (1.52). Semantic extension 8 (see the semantic field section) is constantly present throughout the 16th-century.

In the last quarter century, the use of the 'transfer' meaning of the aan-construction seems to increase. Although we find transfer verbs in the remaining quarter centuries [voortkondigen 'proclaim' (1.33), aanleggen 'lay on' (1.63), verhalen 'recount' (1.54), inbrengen 'bring in' (1.59) and zweren 'swear' (1.50)], those transfer verbs show a relatively low collostructional strength in comparison to the distinctive transfer verbs of the fourth quarter century [bewijzen 'prove' (3.56), geven 'give' (1.71) and to a lesser extent schrijven 'write' (1.44)]. It is, therefore, likely that the 'transfer' meaning of the aan-construction was gaining ground during the 16th-century and that the aan-construction gradually became a full-fledged competitor of the double object construction in the 'transfer' meaning.

The 'transfer' meaning of the aan-construction is a metaphorical meaning extension of the 'contact' meaning.
That 'contact' meaning emerges in the use of the verbs koppelen 'connect' (2.41), verbinden 'connect' (3.19) and hangen 'hang' (1.71). The verbs are distinctive for the third or fourth quarter century. Since these verbs are often combined with an aan-constituent that can be interpreted as a spatial prepositional phrase, we have been very strict during the manual analysis: once the aan-constituent could be replaced by a prepositional phrase with a different spatial preposition, the aan-constituent was considered as a locational prepositional phrase and therefore not taken into account. Since koppelen 'connect', verbinden 'connect' and hangen 'hang' clearly point to 'contact', it is not surprising that they often occur in the aan-construction.

Based on the increase in the use of transfer verbs in the aan-construction, we conclude that the 16th-century aanconstruction is more and more open to metaphorical contexts. The question now is whether we can observe the same evolution in the relationship between the aan-construction and the double object construction in 16th-century Dutch, which we will examine in the next section.

\section{Onomasiological study}

In the onomasiological part of this research we carry out two distinctive collexeme analyses; one for the second quarter century and one for the fourth quarter century. Based on the results of the two distinctive collexeme analyses we examine whether (semantic) shifts can be observed in the ratio between the 16th-century aan-construction and double object construction.

\section{Second quarter century}

Instead of comparing historical periods of a construction (see the diachronic collexeme analysis section) the distinctive collexeme analysis compares competing constructions within the same time period in order to ascertain which lexemes have a preference for one of the tested constructions. Since the distinctive collexeme analysis works the same way as the diachronic collexeme analysis, there is no need for further explanation about the operation of the statistical test. Table 4 presents the results of the distinctive collexeme analysis for the second quarter century. Only 21 out of the 27 examined verbs occur in the second quarter century in one or both constructions. The remaining verbs are therefore not included in the statistical test. The distinctive collexeme analysis (CollStr $>1.30 ; p<0.05$ ) yielded nine distinctive collexemes: three for the double object construction and six for the aanconstruction. The table also shows the non-significant verbs and their preferred construction, because the test is based only on a small data set, so that even small shifts in constructional preference can be observed.

Among the verbs that show a preference for the aanconstruction, we can distinguish two major groups. The first group of verbs are concrete transfers. Thus, there is a spatial displacement of the direct object. This verb group includes the significant verbs zenden 'send' (4.11) and brengen 
TABLE 4: Results of the distinctive collexeme analysis of the second quarter century (1526-1550).

\begin{tabular}{llcc}
\hline Construction & Verb & $\begin{array}{c}\text { Instances per } \\
\text { construction }\end{array}$ & CollStr \\
\hline Double object & geven [give] & $119: 1$ & 19.68 \\
construction $\dagger$ & schenken [gift] & $16: 0$ & $\mathbf{2 . 2 2}$ \\
& verkopen [sell] & $14: 0$ & 1.93 \\
& zeggen [say] & $6: 0$ & 0.82 \\
& wedergeven [give back] & $4: 0$ & 0.54 \\
& bewijzen [prove] & $2: 0$ & 0.27 \\
& ontzeggen [deny] & $2: 0$ & 0.27 \\
& overbrengen [transfer] & $2: 0$ & 0.27 \\
& wijzen [point] & $2: 0$ & 0.27 \\
& doen [do] & $23: 8$ & 0.26 \\
& plegen [commit] & $1: 0$ & 0.13 \\
& tonen [show] & $1: 0$ & 0.13 \\
& verhalen [recount] & $0: 13$ & 7.80 \\
Verzoeken [request] & $12: 23$ & 6.59 \\
Aan-construction & zenden [send] & $0: 7$ & 4.11 \\
& schrijven [write] & $1: 5$ & $\mathbf{2 . 2 4}$ \\
& brengen [bring] & $\mathbf{7 : 9}$ & $\mathbf{2 . 0 1}$ \\
& nemen [take] & $\mathbf{6 : 8}$ & $\mathbf{1 . 8 8}$ \\
& Overdragen [transfer] & $2: 3$ & 0.92 \\
dragen [carry] & $1: 2$ & 0.76 \\
& Overzenden [ship] & $2: 2$ & 0.54 \\
\hline
\end{tabular}

$\dagger, N=223 ; \uparrow, N=79$.

CollStr, collostructional strength

Note: Significant collexemes are marked in bold.

'bring' (2.01), and the non-significant verbs overdragen 'transfer' (0.92), dragen 'carry' (0.76) and overzenden 'ship' (0.54). The distinctive collexemes of the double object construction, geven 'give' (19.68), schenken 'gift' (2.22) and verkopen 'sell' (1.93), on the other hand can represent both concrete and abstract transfers. Although wedergeven 'give back' (0.54) and overbrengen 'transfer' (0.27) only indicate concrete transfers, they also show a preference for the double object construction. However, their preference for the double object construction is not significant. All other verbs that show an (albeit not significant) preference for the double object construction only denote abstract transfers, actions or communicative transfers. So it seems that in the second quarter century especially verbs that denote concrete transfers have a preference for the aan-construction.

With the verbs zenden 'send' (4.11), schrijven 'write' (2.24) and brengen 'bring' (2.01), there is also a degree of conceptual distance between the subject and the indirect object. Thompson and Koide (1987:405-406) indicate that the conceptual distance between the agent and the recipient correlates with the 'linguistic' distance between the agent and the recipient in the sentence. In the aan-construction, the distance between the two roles becomes bigger, so the aanconstruction appears to be a suitable way to indicate the distance to be covered.

The second group of verbs that prefer the aan-construction are the verbs with which the aan-object realises a source role or a dual role. Verhalen 'recount' (7.80) and nemen 'take' (1.88) are verbs with which the aan-object realises a source object. Note that the meaning of verhalen 'recount' is different in the 16th-century from nowadays. One of the meanings of verhalen we can find in the VMNW (Pijnenburg 2001) reads 'recover, demand, (re)claim. In the construction iet verhalen ane enen'.

Using the verb verzoeken 'request', we will explain what is meant by the dual role of the aan-object. The aan-object mainly fulfils the role of recipient with the verb verzoeken 'request', as it is the recipient of the request. However, the subject expects (to receive) something of the aan-object, as is illustrated by the following example:

(13) Soo wie iemanden wonde oft quetste in evelen moede, oftanderssints met wercken misdede, ende aen den drossaert oft sijnen stadt-houder binnen vier-en-twintigh uren gheen vrede en versochte, verbeurtden hooghsten wille van t'sestigh gouden realen. [So who wounded or hurt someone in audacity, or otherwise offended, and did not request peace from the sheriff or his stadholder within 24 hours, forfeits the highest will of sixty golden reals].

(Unknown author - Costuijmen van Deurne)

The aan-object in (13) performs a dual role: it is the recipient of the request, but at the same time it is the supposed 'source' of peace. That interpretation of the object is certainly up for discussion but does not sound that illogical, as the aan-object also takes the role source with the verbs verhalen 'recount' and nemen 'take'. Colleman (2010) already pointed out that the aanobject occurred as a source object before it occurred as a recipient. Both findings would seem to indicate that the ditransitive transfer in the aan-construction emerged from the use of privative verbs, that is, verbs of dispossession, in the aan-construction. Verbs with which the aan-object occupies a so-called dual role, such as verzoeken 'request', maybe formed a bridge between both uses of the aan-construction.

\section{Fourth quarter century}

Again, we carry out a distinctive collexeme analysis, but this time for the fourth quarter century. In the fourth quarter century, 25 of the 27 examined verbs occur at least once in one or both constructions and are thus taken into account. Eight of them were found to be distinctive collexemes: two verbs for the double object construction and six verbs for the aanconstruction (Table 5).

Among the distinctive collexemes of the aan-construction we mainly find the same verbs as in the second quarter century: schrijven 'write' (7.61), nemen 'take' (6.13), verzoeken 'request' (4.96), verhalen 'recount' (3.40) and zenden 'send' (2.05). A few shifts in the collostructional strength can be observed; however, they are not remarkable. Overbrengen 'transfer' (1.35) is a new distinctive collexeme and fits within the group of concrete transfers. It is also an example of the type of particle verbs with a strong preference for the aan-construction in present-day Dutch (Colleman 2009a:605). It is remarkable that overzenden 'ship' nowadays has a strong preference for the aan-construction, but in the fourth quarter century a (nonsignificant) preference for the double object construction (0.21). However, the figures of overzenden 'ship' are low, and it does show a slight preference for the aan-construction in the second quarter century. Also the verbs brengen 'bring' 
TABLE 5: Results of the distinctive collexeme analysis for the fourth quarter century (1576-1600)

\begin{tabular}{|c|c|c|c|}
\hline Construction & Verb & $\begin{array}{l}\text { Instances per } \\
\text { construction }\end{array}$ & CollStr \\
\hline \multirow{11}{*}{$\begin{array}{l}\text { Double object } \\
\text { construction } \dagger\end{array}$} & geven [give] & $179: 6$ & 16.95 \\
\hline & zeggen [say] & $16: 0$ & 1.69 \\
\hline & toeschrijven [attribute] & $12: 0$ & 1.26 \\
\hline & vertellen [tell] & $8: 0$ & 0.84 \\
\hline & schenken [gift] & $6: 0$ & 0.63 \\
\hline & wedergeven [give back] & $5: 0$ & 0.52 \\
\hline & onderwerpen [subject] & $4: 0$ & 0.42 \\
\hline & toestaan [allow] & $3: 0$ & 0.31 \\
\hline & overzenden [ship] & $2: 0$ & 0.21 \\
\hline & verkopen [sell] & $4: 1$ & 0.15 \\
\hline & meegeven [endow] & $1: 0$ & 0.10 \\
\hline \multirow[t]{14}{*}{ Aan-construction $\nleftarrow$} & schrijven [write] & $0: 11$ & 7.61 \\
\hline & nemen [take] & $5: 14$ & 6.13 \\
\hline & verzoeken [request] & $5: 12$ & 4.96 \\
\hline & verhalen [recount] & $0: 5$ & 3.40 \\
\hline & zenden [send] & $8: 8$ & 2.05 \\
\hline & overbrengen [transfer] & $0: 2$ & 1.35 \\
\hline & brengen [bring] & $7: 4$ & 0.73 \\
\hline & doen [do] & $32: 12$ & 0.70 \\
\hline & plegen [commit] & $0: 1$ & 0.67 \\
\hline & tonen $[$ show] & $7: 3$ & 0.44 \\
\hline & wijzen [point] & $4: 2$ & 0.43 \\
\hline & bewijzen [prove] & $29: 9$ & 0.38 \\
\hline & dragen [carry] & $2: 1$ & 0.29 \\
\hline & werpen [throw] & $2: 1$ & 0.29 \\
\hline
\end{tabular}

$\dagger, N=341 ; \ddagger, N=74$

Collstr, collostructional strength.

Note: Significant collexemes are marked in bold.

(0.73) and dragen 'carry' (0.29) still show a preference for the aan-construction, but no significant one, as the CollStr is not higher than 1.33. Also the ballistic verb werpen 'throw' (0.29) shows a non-significant preference for the aan-construction.

Among the other verbs showing a (non-significant) preference for the aan-construction, we find a whole new group of verbs, that is, verbs which denote abstract transfers: the action verbs doen 'do' (0.70), plegen 'commit' (0.67) and bewijzen 'prove' (0.38), and the communicative verbs tonen 'show' (0.44) and wijzen 'point' (0.43). While those verbs still preferred the double object construction over the aan-construction in the second quarter century, they prefer the aan-construction in the fourth quarter century. From this we can cautiously conclude that the collostructional semantics of the aanconstruction has expanded to include abstract transfers during the 16th-century.

The majority of verbs indicating abstract transfers still show a preference for the double object construction: zeggen 'say' (1.69), toeschrijven 'attribute' (1.26), vertellen 'tell' (0.84), onderwerpen 'subject' (0.42) and toestaan 'allow' (0.31). Verbs that can realise both concrete and abstract transfers, geven 'give' (16.95), schenken 'gift' (0.63) and verkopen 'sell' (0.15), decreased in collostructional strength but still show a preference for the double object construction. Based on these findings we can conclude that not all abstract transfer verbs experienced a sudden reversal in constructional preference, though the meaning of the aan-construction has clearly expanded by its use of abstract transfers.

\section{Conclusion}

In this article we tried to outline the semantic evolution of the 16th-century aan-construction. We did this by first mapping the semantic field of the aan-construction. This exercise has shown that the semantic network of the aan-construction was limited to transfers (e.g. brengen 'bring') and contact relationships between the subject and the direct object, of which the aan-object is regarded as the starting point (e.g. zien 'see' and merken 'perceive'). We then conducted a diachronic collexeme analysis to get a better understanding of the semantic evolution of the aan-construction during the 16th-century. The diachronic collexeme analysis showed that in the second half, especially the fourth quarter century, the metaphorical meaning extension of the aan-construction was gaining ground (e.g. zweren 'swear' and bewijzen 'prove'). Because the 'transfer' meaning of the aan-construction plays a major role in that evolution, we also went deeper into the ratio between the double object construction and the aan-construction.

Based on the comparison of the distinctive collexeme analyses of the second and the fourth quarter century, we have examined whether any semantic shifts have occurred within the 'transfer' meaning. The results show that we indeed with caution - can say that the first transfers in the aanconstruction were concrete transfers (e.g. zenden 'send'). Later abstract transfers, including actions and communicative verbs, would become more and more possible because of a metaphorical meaning extension of the aan-construction (e.g. verzoeken 'request' and doen 'do').

Additionally, based on our findings, we created a new hypothesis about the semantic evolution of the aanconstruction. Previous research had already pointed out that the use of the aan-object as a source object is older than the use of the aan-object as recipient. In our own corpus data, we concluded that the aan-object can play a dual role, both as a recipient and as a source object, with certain verbs. Our hypothesis is that these verbs have formed a bridge between the privative (and older) meaning of the aan-construction and the ditransitive (and younger) meaning. This means that the first ditransitive verbs, which could occur in the aanconstruction, were verbs of dispossession (e.g. nemen 'take'). Then also verbs with which the aan-object takes a dual role (e.g. verzoeken 'request') could occur with the preposition aan. Only after this step could prototypical ditransitive verbs (e.g. geven 'give') also occur in the aan-construction.

This new hypothesis shows that the last word has not been said about the aan-construction; on the contrary, this hypothesis raises many new questions and brings many new avenues with it. One of the possible avenues is investigating the relationship between privative and 'normal' transfers and examining which role privative verbs have in the evolution of the aan-construction (and the double object construction). 


\section{Acknowledgements}

The author wish to acknowledge and thank Timothy Colleman, his supervisor, Tim Geleyn, co-supervisor, and the two anonymous reviewers for their helpful comments and suggestions. Usual disclaimers apply. This is a translated version of Rens (2015) in order to make it available to a broader audience. Rens (2015) was published in Buysschaert (2015), a special issue comprising articles based on master's theses of students at Ghent University, only distributed to alumni of the Germanic languages at Ghent University.

\section{Competing interests}

The author declares that he has no financial or personal relationships that may have inappropriately influenced him in writing this article.

\section{References}

Barđdal, J., Smirnova, E., Sommerer, L. \& Gildea, S. (eds.), 2015, Diachronic construction grammar, John Benjamins, Amsterdam.

Buysschaert, J. (ed.), 2015, Over talen en tekens. Bijdragen van jonge Gentse linguïsten, Academia Press, Gent.

Colleman, T., 2009a, 'Verb disposition and argument structure alternations: A corpus study of the Dutch dative alternation', Language Sciences 31(5), 593-611. https:// doi.org/10.1016/j.langsci.2008.01.001

Colleman, T., 2009b, 'The semantic range of the Dutch double object construction Acollostructional perspective', Constructions and Frames 1(2), 190-221. https:// doi.org/10.1075/cf.1.2.02col

Colleman, T., 2010, 'Beyond the dative alternation: The semantics of the Dutch aandative', in D. Glynn \& K. Fischer (eds.), Quantitative methods in cognitive semantics: Corpus-driven approaches, pp. 271-303, Mouton de Gruyter, Berlin.

Colleman, T., 2011, 'Ditransitive verbs and the ditransitive construction: A diachronic perspective', ZeitschriftfürAnglistik und Amerikanistik 59(4), 387-410. https://doi. org/10.1515/zaa-2011-0408

Colleman, T. \& De Clerck, B., 2009, “"Caused motion?" The semantics of the English to-dative and the Dutch aan-dative', Cognitive Linguistics 20(1), 5-42. https://doi. to-dative and the Dutch aan-dat
org/10.1515/COGL.2009.002

Colleman, T. \& De Clerck, B., 2011, 'Constructional semantics on the move: On semantic specialization in the English double object construction', Cognitive Linguistics 22(1), 183-209. https://doi.org/10.1515/cogl.2011.008

Croft, W., 2001, Radical construction grammar: Syntactic theory in typological perspective, Oxford University Press, Oxford.

De Schutter, G., 1974, De Nederlandse zin: Poging tot beschrijving van zijn structuur, De Tempel, Brugge.
De Vries, M. \& Te Winkel, L.A. (eds.), 1882-1998, 'WNT', in Woordenboek der Nederlandsche Taal, Martinus Nijhoff/Brill, 's-Gravenhage.

Duinhoven, A.M., 2003, 'Actieve en passieve indirect objecten: Een kwestie van analyse en synthese', Nederlandse Taalkunde 8(3), 199-230.

Geleyn, T. \& Colleman, T., 2015, 'De aan-constructie in het 17de-eeuwse Nederlands. Eensemasiologischestudie', Taal en Tongval 67(2), 211-245.

Goldberg, A.E., 1995, Constructions: A construction grammar approach to argument structure, University of Chicago Press, Chicago, IL.

Goldberg, A.E., 2003, 'Constructions: A new theoretical approach to language', Cognitive Sciences 7(5), 19-224. https://doi.org/10.1016/s1364-6613(03)00080-9

Gries, S.T., 2007, Coll. Analysis 3.2. A program for $R$ in Windows 2.x.

Gries, S.T., Hampe, B. \& Schönefeld, D., 2005, 'Converging evidence: Bringing together experimental and corpus data on the association of verbs and constructions', Cognitive Linguistics 16(4), 635-676. https://doi.org/10.1515/cogl.2005.16.4.635

Gries, S.T. \& Stefanowitsch, A., 2004, 'Extending collostructional analysis: A corpusbased perspective on "alternations"', International Journal of Corpus Linguistics 9(1), 97-129. https://doi.org/10.1075/ijcl.9.1.06gri

Hilpert, M., 2006, 'Distinctive collexeme analysis and diachrony', Corpus Linguistics and Linguistic Theory 2(2), 243-256. https://doi.org/10.1515/CLLT.2006.012

Pijnenburg, W.J.J., Van Dalen-Oskam, K.H., Depuydt, K.A.C. \& Schoonheim, T.H. (eds.), 2001, 'VMNW', in Vroegmiddelnederlands Woordenboek, Instituut voor Nederlandse Lexicologie, Leiden.

Rens, D., 2014, “'Want die geest geeft getuge onsen geeste." Een constructionee encorpusgebaseerd onderzoek naar de Middelnederlandse objectvolgorde en datiefalternantie', Unpublished Bachelor's thesis, Ghent University.

Rens, D., 2015. 'De zestiende-eeuwse aan-constructie. Een semasiologisch en onomasiologischonderzoek', in Buysschaert, J. (ed.), Over talen en tekens. Bijdragen van jongeGentselinguïsten, pp. 57-76, Academia Press, Gent.

Rohdenburg, G., 2007, 'Functional constraints in syntactic change: The rise and fall of constructions in early and late modern English', English Studies. A Journal of English Language and Literature 88(2), 217-233. https://doi.org/10.1080/ 00138380601042824

Schoonheim, T.H., Louwen, K., Mooijaart, M.A., Pijnenburg, W.J.J. \& Quak, A. (eds.), 2009, 'ONW', in Oudnederlands Woordenboek, Instituut voor Nederlandse Lexicologie, Leiden.

Stefanowitsch, A., 2006, 'Distinctive collexeme analysis and diachrony: A comment' Corpus Linguistics and Linguistic Theory 2(2), 257-262. https://doi.org/10.1515/ CLLT.2006.013

Thompson, S.A. \& Koide, Y., 1987, 'Iconicity and "indirect objects" in English', Journal of Pragmatics 11(3), 399-406.

Traugott, E.C. \& Trousdale, G., 2013, Constructionalization and constructional changes, Oxford University Press, Oxford.

Van Belle, W. \& Van Langendonck, W., 1996, 'The indirect object in Dutch', in W. Van Belle \& W. Van Langendonck (eds.), The dative, volume I: Descriptive studies, pp. 217-250, John Benjamins, Amsterdam.

Van Der Horst, J.M., 2008, Geschiedenis van de Nederlandse syntaxis, Leuven University Press, Leuven.

Van Kemenade, A. \& Los, B., 2013, 'Using historical texts', in R.J. Podesva \& D. Sharma (eds.), Research methods in linguistics, pp. 216-232, Cambridge University Press, Cambridge.

Weijnen, A.A. \& Gordijn, A.M.J., 1970, 'Het binnendringen van het voorzetsel in het indirekt objekt in het Nederlands', Leuvense Bijdragen 59, 125-130. 